\title{
EL MELODRAMA COMO GÉNERO CINEMATOGRÁFICO
}

\section{MELODRAMA AS FILM GENRE}

\begin{abstract}
AUTORA
Graciela Padilla Castillo

Licenciatura en Comunicación Audiovisual. Universidad CEU San Pablo. Madrid (España). elcorreodegraci@hotmail.com
\end{abstract}

\section{RESUMEN}

Este artículo va a intentar desgranar las características comunes de un importante género cinematográfico: el melodrama. Muchas veces se tiende a confundir 0 a mezclar con otros géneros. Pero realmente tiene sus signos propios y una amplia tradición a lo largo de la historia del cine, de la literatura e incluso, de la música. En la Italia del Barroco o en la Francia de los años próximos a la Revolución Francesa, ya se hablaba de melodrama como pieza teatral. El concepto se refería a aquellas obras en las que se combinaban partes habladas con partes musicales. La llegada de nuevos públicos en el siglo XIX, produjo un cambio semántico que se acercaría mucho al significado actual, porque el término melodrama pasaba a abarcar todos los dramas populares escritos en prosa, de argumento sensacionalista o folletinesco y plagado de tintes novelescos. Esos dramas siempre trataban temas similares, con un enfrentamiento entre el bien y el mal, un final feliz, y personajes muy estereotipados.

\section{PALABRAS CLAVE}

Cine - Melodrama - Géneros cinematográficos - Douglas Sirk. 


\section{ABSTRACT}

This article will try to reel off the common characteristics of a major film genre: melodrama. Often tends to confuse or mix with other genres. But it really has its own signs and a long tradition throughout the cinema, literature and even music history. In Baroque Italy or in the coming years of the French Revolution, there was talk of melodrama as a theatrical piece. The concept is referred to works in the spoken parts were combined with musical parts. The arrival of new audiences in the nineteenth century, produced a semantic change that much closer to the actual meaning, because the term melodrama going to cover all popular dramas written in prose, with sensational or melodramatic plot and full of novelistic dyes. These dramas always tried similar themes, with a confrontation between good and evil, a happy ending, and very stereotypical characters.

\section{KEY WORDS}

Cinema - Melodrama - Cinematographic genres - Douglas Sirk.

\section{ÍNDICE}

1. Introducción.

2. Características comunes de todo melodrama.

3. Sentido y aceptación del sufrimiento.

4. Aparición constante del fracaso.

5. El público se hace partícipe del sufrimiento de los personajes.

6. No superación de traumas del pasado, lesiones físicas o psíquicas.

7. Sublimación o represión de los deseos.

8. Guiones con expresiones y palabras cargadas de sentimiento, dolor 0 dramatismo.

9. Acumulación de elementos melodramáticos y de desgracias. 
10. Cualquier tiempo pasado fue mejor.

11. Uso de flash-backs para volver a ese pasado anhelado.

12. Uso de otros recursos sobre el tiempo de la narración.

13. Referencias temporales en los títulos de las películas.

14. Sabia dosificación de la información.

15. Momentos de humor para romper la tensión dramática.

16. Arranques muy significativos.

17. La música.

18. Conclusiones.

19. Bibliografía.

20. Videografía.

\section{Introducción}

Jean Louis Leutrat afirmó que es necesario acudir a las fuentes documentales para entender lo que el melodrama. La primera concepción se refiere a películas de gángsters, donde el protagonista debía defenderse contra una trama criminal. Pero la segunda, en cambio, se refiere a los melodramas familiares o románticos, que llegarían incluso a formar el subgénero de las women's picture, películas para mujeres. A todas esas características sentimentales y operísticas se les unió la del sentido pictórico. Así, el melodrama pasó de ser una pieza teatral con música a convertirse en un texto plagado de efectos pictóricos, aptos para ser trasladados al cine y a la televisión. Combinaba una imagen dinámica, palabra, gestos, música y decorado. 
Aún le faltaba al melodrama empaparse de los gustos y motivaciones del público. En los siglos XIX y XX, tomó muchos elementos de la cultura popular: teatro, pantomima, música, literatura, cómic, canción popular, fotonovela, etc. Asimismo, se relacionó con otros géneros algo afines como el folletín, el dramón, el culebrón, el serial radiofónico, el relato rosa o el anglosajón weepie, mientras intentaba desligarse de géneros superiores, típicos de la nobleza y burguesía, como la tragedia, la ópera o la alta comedia burguesa. Quizá, esas mezclas y sumas de influencias pudieron ser el origen del sentido despectivo que, en algunas ocasiones, se le dio al melodrama. Los cines optaron por apartarlo de sus pantallas y los programas dobles sólo estaban dedicados al películas western, bélicas, de gángsters o de aventuras. Sin embargo, grandes éxitos posteriores como Lo que el viento se llevó o Jezabel harían resucitar el género, que había estado menospreciado y concebido únicamente para el público femenino. Era el renacimiento del melodrama, unido al cambio sociológico de la incorporación de la mujer al mundo laboral y su derecho al voto. Hollywood se dio cuenta de que la mayor parte de su público estaba formado por mujeres y tenían que satisfacerlas, ofreciendo productos que fueran de su gusto, manteniendo siempre la misma calidad exigible a cualquier filme. De ahí vendría el boom de los ya citados women's pictures, tearjerkers ("surtidores de lágrimas"), weepies (del inglés "to weep", equivalente a llorar) o simplemente, melodrama o genre larmoyant para los franceses ("género lacrimógeno").

\section{Características comunes de todo melodrama}

Como todo gran género cinematográfico, el melodrama cuenta siempre con unos elementos que se repiten en todas las películas. Sigue un patrón bastante claro en cuanto a temas, tramas, personajes, desarrollo del guión $y$, a veces, puesta en escena. Los siguientes apartados se refieren a todas esas similitudes que el espectador puede encontrar en una película melodramática, ejemplificadas con las películas estudiadas para este análisis. 


\section{Sentido y aceptación del sufrimiento}

El personaje protagonista recibe, asume y soporta su sufrimiento, muchas veces con pasividad y de manera abnegada. Esto se opone a los héroes tradicionales de otras películas, dotados de atributos épicos y capaces de resolver cualquier problema. El sentimiento de congoja es enorme e ineludible:

- Jackie, en Quédate a mi lado, sabe que puede estar enferma de cáncer. Al público se le oculta una importante información hasta su cita con el médico: ya le habían extirpado un tumor unos meses antes. Pero ese nuevo cáncer es realmente una sorpresa para ella y el espectador, que en todo melodrama suele saber más que los personajes. Cuando la doctora le informa de su situación, dice que luchará y vivirá. Sin embargo, cuando la quimioterapia no cumple el efecto deseado y ve que Isabel cuidará de sus hijos y será una buena madre en su ausencia, acepta la muerte y se prepara para morir. No le queda otra opción y se adapta a ello, despidiéndose de sus hijos.

- Laura, en Breve Encuentro, sabe que su relación adúltera y furtiva nunca podrá salir bien. Ni siquiera se atreve a contárselo a su marido y sólo se atreve a hablarle de ello desde el pensamiento, desde una voz en off que escuchan los espectadores. Asume su dolor y la imposibilidad de cambiar de vida. Y aunque ya no esté enamorada de su esposo, dice "yo soy tu mujer y debo cuidar de ti y de mis hijos", dando la espalda a un futuro incierto, pero apasionado. Es decir, renuncia al verdadero amor para continuar siendo una madre y esposa ejemplar, con una vida perfecta aparentemente, dentro y fuera de casa. Aunque no puede olvidar que ama a otro hombre.

- El personaje de Penélope Cruz, Rosa, en Todo sobre mi madre asume que va a morir de SIDA y sus últimos días los dedica a vivir en casa de Manuela, intentando que su embarazo llegue lo más lejos posible y su hijo nazca. Cuando sabe que su final está cerca, en lugar de encerrarse, va a un hospital 
a morir. De camino a allí, se encontrará a su padre, en el parque, con el perro. Sabe que será la última vez que va a verle, aunque él, enfermo de Alzheimer no puede ya ni reconocerla. Rosa simplemente llora y acepta también que no puede despedirse de él diciéndole que es hija suya; no serviría para nada y sólo conseguiría desconcertarle o enfadarle. Ese encuentro tan tenso uno de los momentos más emotivos de la película. Ella tiene que asumir su desdicha y la de su padre, porque él no se da cuenta de nada.

- Por otra parte, se puede considerar que existen pequeñas excepciones. En Philadelpia, el personaje de Andrew difiere un poco de las características generales del protagonista del melodrama. Tiene un futuro trágico y lo asume; sabe que va morir a causa del SIDA. Pero sigue luchando, no contra la enfermedad (que es irremediable), sino en la batalla legal que inició contra el despacho de abogados que le despidió.

- La fuerza del cariño puede considerarse también una excepción en cuanto a la estructura. El tono de la primera parte de la película es el de una comedia hasta que a Emma, la protagonista, la detectan un cáncer. A partir de ahí, la película cambia el tono narrativo y el espectador se hace a la idea que Emma morirá a causa de la enfermedad. Así que es el espectador el que asume también ese destino trágico.

- Rafa (Antonio Resines), el protagonista de La buena estrella, es un hombre castrado que vive con ese problema serenamente. A lo largo de la película, el problema sale a la luz en diferentes ocasiones, ante las cuales Rafa actúa de forma resignada y serena.

\section{Aparición constante del fracaso}

Todo personaje melodramático siente que ha fracasado en algún aspecto de la vida. Douglas Sirk, gran maestro del melodrama, se refería a ese fracaso como échec, término francés y lo definía así: "En francés, échec significa mucho más que fracaso; 
significa no tener salida, estar bloqueado, y por esta misma razón, es un término más válido que fracaso. No me interesa el fracaso en el sentido que le dan los neorrománticos, que defienden la belleza del fracaso. Es más bien el tipo de fracaso que se apodera de ti sin ton ni son. Es un espantoso tipo de fracaso.

- En Escrito sobre el viento, Kyle Hadley es joven, guapo y millonario. Pero es un bebedor, ludópata y maniático, porque incluso guarda un arma bajo la almohada. Todo a su alrededor parece perfecto. No tiene problemas económicos. Tiene cualquier capricho a su alcance. Se divierte viajando en su avión privado. Pero en el fondo, se siente como un auténtico fracasado porque su mejor amigo, Match, es todo lo que él deseó ser, desde sincero, hasta buena persona y buen amigo.

- Por ejemplo, en Philadelphia hay un momento en el que Andrew (Tom Hanks) está en una fiesta y al darse cuenta de su debilidad se viene abajo, física y moralmente. Esto le hace pensar que no va a poder terminar el juicio en el que está embarcado. Siente que por culpa de su enfermedad no va a poder llegar al fin que se ha propuesto y que va a fracasar.

\section{El público se hace partícipe del sufrimiento de los personajes}

La experiencia de sufrimiento llega a rozar lo masoquista en el espectador, que siente simpatía hacia esos héroes sufrientes en los que puede verse reconocido y con los que decide compartir sus desgracias. El espectador tiene que padecer también, emocionarse, llorar; ese es el principal objetivo del melodrama: involucrar y emocionar. Si no es así, estaríamos ante otro género. Para conseguirlo, el guionista dosifica a lo largo de la película las "malas noticias" que se van dando a los personajes. Así mantiene esa identificación personaje - espectador, porque los dos se sienten asustados y temen saber qué pasará. Aunque es el espectador el que suele saber más que el personaje: 
- En La fuerza del cariño se presenta a Emma como una mujer alegre y divertida, una madre que adora a sus hijos y a su madre. Es extrovertida y suele estar siempre de buen humor. Es un personaje simpático, pero poco a poco se van presentando trabas a esa vida perfecta: los engaños en su matrimonio, la falta de dinero, los enfados con su madre y definitivamente, el cáncer. Esta manera de dar información de manera dosificada, a lo largo de la película, para mantener la tensión dramática, también ayuda a establecer esa relación con el espectador.

- En La buena estrella, el espectador desea que le vayan bien las cosas a Dani (Jordi Mollá), un delincuente que no para de meterse en líos. Lleva una vida de continuas penurias desde su más tierna infancia que, de cierta manera, han marcado su vida inevitablemente. Pero así como Dani, en La buena estrella, todos los personajes están sometidos por un fatum inevitable, un destino único: la vivencia trágica.

\section{No superación de traumas del pasado, lesiones físicas o psíquicas}

Los protagonistas del melodrama suelen tener heridas en el alma que nunca han cicatrizado y marcan su vida presente, llevándoles hacia el dolor y el sufrimiento.

- La vida de Laura, en Breve encuentro, está marcada por una aventura amorosa ya pasada. Pero a pesar de que sea algo que ya debería haber olvidado, sigue marcando su vida familiar y conyugal.

- En La buena estrella, el personaje de Rafa, es un hombre maduro al cual, la pérdida de su madre le marcó para siempre, al igual que la influencia de su familia. Marina (Maribel Verdú) vivió de pequeña en un reformatorio donde la trataban mal y la consideraban estúpida. Esto creó un complejo de inferioridad muy acentuado que le hizo despreciar la vida en sí, la propia felicidad. El tercer personaje de la buena estrella, Dani, vivió junto a Marina las mismas 
penurias y sobrevivió toda su vida de los trapicheos y de la delincuencia, pasando en la cárcel gran parte de su vida.

- Manuela, de Todo sobre mi madre, y toda su vida van a estar marcadas por la muerte de su hijo Esteban. La peripecia principal de la película comienza concretamente cuando Manuela va a ver a la actriz Huma Rojo, recordando aquel autógrafo que su hijo no pudo conseguir antes de ser atropellado a la salida del teatro.

- Kyle Hadley, el protagonista de Escrito sobre el viento, vive marcado por su infancia. Fue un niño rico y mimado. Su mejor amigo de toda la vida es Match. Desde sus juegos infantiles se ha sentido inferior a él, porque todos alababan sus virtudes. Ese odio interior que desarrolla hacia Match marcará su matrimonio y su muerte, debido a la desconfianza y a la envidia reprimida durante años.

\section{Sublimación o represión de los deseos}

A veces, el dolor de los protagonistas viene de la represión de un deseo que necesitan cumplir por encima de todo. Puede que sus vidas sean aparentemente perfectas. Pero siempre hay algo callado u oculto que les hace sufrir. Puede ser un amor secreto, la necesidad de desvelar que una enfermedad les está matando, el sueño de cambiar de vida o simplemente, la necesidad de querer sincerarse con alguien y hablar de su dolor.

- Rosa es el personaje más reprimido de Todo sobre mi madre, porque la situación le ha llevado a ello. Se va a morir de SIDA, estando embarazada de un bebé al que puede contagiar la enfermedad. Esta enfermedad se la transmitió un antiguo amor, ahora travestido, que también está muriendo de sida y no quiere conocer a su hijo. $Y$ en medio de esta situación, siente el dolor de no poder acercarse a sus padres. Su padre está enfermo de Alzheimer y no la reconocería. Pero su madre, que sí está completamente 
lúcida, ya no la reconoce como su hija y no quiere verla, porque no encaja en sus planes y estatus de vida.

- Rafa, en La buena estrella, llega a un momento de felicidad y estabilidad con Marina que él recibe como un milagro. Pero todo cambiará con la llegada de Dani, y por el amor hacia Marina, Rafa dejará que Dani viva con ellos. Aquí se produce una represión emocional por parte de Rafa que no cesa hasta la muerte de Dani.

- En Philadelphia, cuando Andrew Beckett descubre que tiene el SIDA pretende ocultarlo a toda costa. Incluso pretende esconder su homosexualidad al resto de sus compañeros, porque desvelarlo le costaría el puesto de trabajo. Esta es una de las razones que le hace desgraciado, porque tiene que esconder su verdadera manera de ser. Liberar esos sentimientos le hará morir con paz y dignidad.

- En La fuerza del cariño, cuando Emma está en el hospital pospone hablar con sus hijos porque quiere ocultarles que va a morir. Por ello, la tensión se va acumulando hasta que llega una de las escenas cumbre de la película en la que Emma y sus hijos se despiden. Necesitaba contarles la verdad antes de morir.

\section{Guiones con expresiones y palabras cargadas de sentimiento, dolor o dramatismo}

Los protagonistas del melodrama sufren y aman apasionadamente y el espectador lo sabe al ver sus gestos, su comportamiento y cómo se desarrollan en su entorno. Pero además, en este género, la palabra toma una fuerza inusitada. Sí es cierto que, a veces, se sabe más de sufrimiento por lo que no dicen. Pero la verdad es que generalmente, los personajes suelen hablar abiertamente por de sus sentimientos, por su propia voz, en una carta o a través de un diario. Siempre se sinceran ante el público con grandes frases o soliloquios que incluyen expresiones como éstas: 
- "Él se va en dirección opuesta, a África. Esta tristeza no puede durar. No hay nada que dure siempre"; (Laura, en Breve Encuentro).

- "Sabes lo que ha pasado? Me he enamorado"; (Laura, en Breve Encuentro).

- "Debemos olvidar"; (Laura, en Breve Encuentro).

- "Quiero olvidar, volver a mi estado anterior"; (Laura, en Breve Encuentro).

- "He estado a punto de hacerlo, de tirarme a la vía. Y no te puedo decir que no lo haya hecho por ti y por los niños. Lo hice porque no le volvería a ver"; (Laura, en Breve Encuentro).

- "¿Qué si te quiero? Yo no quiero a nadie, ni siquiera a mí mismo" (Kyle a su esposa, en Escrito sobre el viento).

- "Cásate conmigo o diré a la Policía que tú mataste a mi hermano" (la hermana de Kyle haciendo chantaje a Match, tras el suicidio, en Escrito sobre el viento).

- "¿Por qué Isabel vive con nosotros? Tú ya compartías tu vida con mamá"; (Anna, en Quédate a mi lado).

- "Mamá, si tú quieres que la odie, yo lo haré"; (Ben a Jackie en Quédate a mi lado).

- "Cásate conmigo. Quiero vivir esa decisión todos los días, incluso aún cuando el amor penda de un hilo, no dejaré que se vuelva a romper"; (Lucke a Isabel, en Quédate a mi lado, cuando la pide matrimonio).

- "Lo pasaremos juntos. No estás solas"; (Lucke a Jackie, su ex mujer, en Quédate a mi lado, cuando ésta le desvela que tiene cáncer).

- "Yo soy un hombre, un hombre herido, mutilado, pero soy un hombre"; (Rafa en La buena estrella.)

\section{Acumulación de elementos melodramáticos y de desgracias}

Algunos melodramas tienden al exceso al incluir todo tipo de fracasos y penurias en la vida y el sentir de los personajes. 
- Pedro Almodóvar es el mejor representante de ello, pues demuestra saber hacerlo con gran maestría en Todo sobre mi madre, donde reúne muchos clásicos de melodramas en uno: Una madre pierde a su hijo adolescente a la salida del teatro, una misionera enferma de sida sabe que va a morir estando embarazada, un anciano de Alzheimer está totalmente alejado de su familia y de la realidad, y un travestido también moribundo por tener sida no conocerá a su hijo y no se ha despedido de esa antigua novia, la misionera monja, antes de que muriera.

- En La buena estrella se produce una relación triangular entre los tres personajes principales, en la que Marina ama a los dos con la misma intensidad -a cada uno por un motivo diferente- y no puede desprenderse de ninguno.

\section{Cualquier tiempo pasado fue mejor}

Los protagonistas anhelan muchas veces un pasado en el que encuentran buenos e inolvidables momentos que remarcan su desdicha en el presente. Su dolor crece porque saben que es imposible recuperar ese pasado y ese tiempo perdido. Puede ser que recuerden una infancia feliz, un viejo amor o la nostalgia de la perdida juventud, siempre huyendo, irremediablemente, del presente. Por eso tienden a repetir muchas veces la palabra "nunca" como en Rebeca ("Nunca volveré a Manderlay').

- Dani, en La buena estrella, antes de morir le dice a Rafa: "Daniel Expósito nunca le debe nada a nadie".

- Jackie, en Quédate a mi lado, antes de saber que va a morir, siempre les dice a sus hijos que nunca digan "nunca", porque trae mala suerte. $Y$ si quieren decirlo, es mejor decirlo dos veces "nunca, nunca". Esto surge cuando Anna le dice a su madre que nunca querrá a I sabel y que la odia. 


\section{Uso de flash-backs para volver a ese pasado anhelado}

Los personajes buscan recordar y rememorar lo que ya vivieron, buscando en el recuerdo la disminución de su sufrimiento, aunque siempre se produzca el efecto contrario.

- Toda la película de Breve Encuentro es un gran flash-back, en el que Laura vuelve al pasado para contarnos su gran historia de amor. Conoció al amor de su vida y al final, no acabaron juntos. Pero necesita compartir esos sentimientos. Hace que se lo cuenta a su marido aunque, en realidad, lo callará toda su vida, hasta que muera con sus recuerdos o con ella misma, según sus propias palabras. Su voz en off, desde el segundo minuto, nos hace ver que es una historia pasada que no ha podido olvidar.

- Manuela, en Todo sobre mi madre, recuerda alguna muchas veces la muerte de su hijo y tiene mucha fuerza esa imagen nocturna, con lluvia, fuera del teatro y antes de que Esteban muera. Pero para no volver muchas veces a esa escena tan dura, Almodóvar también se refiere a Esteban cuando su madre revisa sus cosas y la última foto que tiene de él.

\section{Uso de otros recursos sobre el tiempo de la narración}

Elipsis abruptas, sobreimpresiones, fundidos, aparición de elementos que hablan del paso de tiempo (relojes, calendarios).

- Escrito sobre el viento es un buen ejemplo con su secuencia central, que comienza tras una elipsis que traslada la acción a un año después del matrimonio de Kyle y Lucy. El aniversario es celebrado con una fiesta paradójica, donde la falsa alegría está intentado ocultar todas las carencias de los protagonistas. 
- Breve Encuentro utiliza fundidos para empalmar cada secuencia porque todo es algo pasado, un gran flash - back, algo que Laura está recordando en su cabeza. Todas las imágenes adquieren así un tinte borroso, algo onírico, como si sólo hubiera ocurrido para ella y no para el resto del mundo, porque morirá ocultando el secreto de ese amor.

- La fuerza del cariño usa constantemente elipsis, ya que abarca un largo periodo de tiempo. Cuenta la vida entera de una mujer que muere, dejando tres hijos. El uso de las elipsis se observa perfectamente con los niños, ya que cada vez son actores diferentes; primero bebés, luego niños y luego preadolescentes.

\section{Referencias temporales en los títulos de las películas}

Por si todos los elementos o recursos que aluden al paso del tiempo no fueran suficientes, los títulos de los filmes también suelen referirse directamente a ello. Hay muchísimos ejemplos si se consulta cualquier lista sobre el género melodramático, tanto en sus nombres originales como traducidos al español:

- Niebla en el pasado (1942, de Melvyn Le Roy).

- Te volveré a ver (1944, de William Dieterle).

- Fuego de juventud (1945, de Clarence Brown).

- Los mejores años de nuestra vida (1946, de William Wyler).

- Breve encuentro (1946, de David Lean).

- De aquí a la eternidad (1953, de Fred Zinnemann).

- Siempre hay un mañana (1955, de Douglas Sirk).

- Tal como éramos (1973, de Sydney Pollack). 


\section{Sabia dosificación de la información ${ }^{1}$}

El melodrama necesita hacer partícipe al espectador de la desgracia incluso antes de que ésta se produzca. Siempre suele contar con más información que los protagonistas. Se le revela un secreto que le hace sentir simpatía por los personajes y por la historia. Por ello, el guión debe cuidar muy bien cómo da esa información y cómo la reparte a lo largo del tiempo fílmico, para ganarse esa empatía y no perderla, sino fortalecerla.

\section{Momentos de humor para romper la tensión dramática}

Ningún espectador puede aguantar ciento veinte minutos de drama. Por eso, todas las historias tienen ciertos momentos más distendidos y agradables, incluso humorísticos, que pueden despertar una sonrisa y relajar la tensión de la película.

- La camarera y el revisor de la estación ponen el punto de humor a Breve Encuentro. Ella parece una mujer agria y quejica. Pero el revisor despierta su lado romántico y ambos viven una relación amorosa peculiar y divertida. Unos hombres llegan a acosarla y su amado la defiende como todo un caballero. A partir de ahí, los dos han manifestado abiertamente la atracción y el cariño que sienten uno por el otro.

- Bobby, el hijo de Laura en Breve Encuentro, también pone un punto de humor. Es atropellado por un coche, sin ser apenas herido y quiere mostrarse como un gran héroe, un valiente, como un fantástico chiquillo. Es su cumpleaños y quería ir al circo o a los polichinelas, pero se queja por no poder hacer lo que quería, mientras su madre vive un dilema interna mucho más profundo en el que se plantea abandonar a su familia por un desconocido.

\footnotetext{
${ }^{1}$ Para ahondar más en este concepto, véase la tesis doctoral: CALDEVILLA DOMíNGUEZ, David (2000): El estilema de autor en Steven Spielberg. Universidad Complutense. Madrid. En esta tesis se plantea el concepto de bucle o espiral de información para hacer avanzar la historia sin caer en vacíos, generando complicidad descodificadora en el espectador.
} 
- Isabel, en Quédate a mi lado, es una fotógrafa profesional. Siempre llega tarde a las sesiones y su jefe la recrimina. Pero en cinco minutos, le sorprende con un trabajo original e inesperado. Lo más gracioso es cuando convierte en protagonista de un anuncio de trajes de Valentino a un camarero bajito y gordito que llevaba unos canapés a las espectaculares modelos.

- Ben, el niño de Quédate a mi lado, es el personaje que más humor da a la película. Es un niño y siempre está bromeando. Su humor y su inocencia dan un poco de relajación a la tensión de saber que su madre va a morir en poco tiempo. Los mejores momentos son sus trucos de magia, que los hace incluso en la comisaría, con los policías que le han encontrado sólo en Central Park. También es divertido cuando se encierra en un armario de la cocina, a la hora del desayuno, mientras I sabel le está buscando, y cuando le dice a su madre por teléfono que es "telepatético" y "patatélico" en lugar de "telepático". Ese momento es un poco paradójico, porque a Jackie está ingresada, recibiendo quimioterapia y no les ha dicho a sus hijos la verdad. Es la primera vez que se separa de sus hijos y llora, porque empieza a imaginarse lo que será dejarles sin su presencia.

- En Todo sobre mi madre, el monólogo realizado por Agrado (Antonia San Juan) en la función de teatro. Alivia al espectador y rompe la tensión del drama. Agrado, al no poderse realizar la función, sale al escenario y cuanta la historia de su peculiar vida.

- Roberto Benigni en La vida es bella. Durante toda la película es un gran cómico, animado y cariñoso para el público. Intenta hacer creer a su hijo que la estancia en el campo de concentración es sólo un juego y para conseguirlo, tiene que hacer bromas y parodias sobre cada acción o insulto de los alemanes. Un gran momento se produce cuando Guido (Benigni) comienza a traducir las palabras del soldado alemán, dentro de los barracones del campo de concentración. Guido inventa la traducción para que su hijo crea que habla de las normas de un juego que va a comenzar, pero que en realidad se trata de una estancia en el campo de exterminio. 
- En La buena estrella, el personaje de Dani está construido como un personaje ideal para la creación de conflictos e igualmente para aliviar la carga dramática en muchos momentos de la historia. La personalidad de Dani y su forma de actuar tienen, de alguna manera, una gracia natural.

- En Philadelphia, Joe Miller, el abogado, está haciendo la compra y le confunden con un homosexual. Esto es algo que le molesta y posteriormente se le ve en una fiesta de disfraces en la que todos los asistentes son homosexuales.

- En La fuerza del cariño, hay una escena en la que Jack Nicholson, completamente borracho, conduce su deportivo por la playa. Shirley MacLaine, su acompañante, está asustada y utiliza el freno de mano, provocando que él salga disparado hacia el agua.

\section{Arranques muy significativos}

Todo buen melodrama tiene que cumplir las reglas clásicas y presentarnos en los primeros 6-10 minutos de qué va a ir la película. Nos presenta a los personajes principales, en su entorno y con el carácter que les define y va a marcar su manera de vivir la tragedia. Además, se nos puede dar ya concretamente cuál va a ser el motivo de su sufrimiento 0 , por lo menos, se dejará entrever el tono y el espectador sabrá que algo no va a bien, que va a ver algún problema y se lo puede ir imaginando. Los melodramas nunca mienten.

- En La buena estrella la introducción presenta imágenes de un matadero. Son imágenes impactantes y duras de animales muertos y mutilados que, metafóricamente aluden a la situación y al tipo de vida de los personajes.

- Breve encuentro arranca con el tren entrando en la estación y un diálogo divertido entre un revisor y la camarera del bar. Sin embargo, desoyendo sus palabras y su presencia, al fondo de la escena ya están los dos protagonistas conversando de manera extraña y apesadumbrada, temiendo mirarse a los 
ojos. El espectador ya sabe, en el minuto tercero, que les une una relación especial y que algo no va bien entre ellos. Poco después, sabemos sus nombres: Alec y Laura. Él dice que va a ir "en dirección opuesta: a África". Y una voz en off, la de Laura, empieza a contarnos esa historia pasada que era un flash-back: "Me gustaría poder olvidarle...".

- Quédate a mi lado da en los primeros minutos las claves para entender la película. I sabel (Julia Roberts) abre los ojos, tumbada en la cama, y se levanta rápidamente porque se ha quedado dormida. Es un auténtico desastre. Mientras va a la cocina, dice a los niños que desayunen pero estos ya lo han hecho, se han vestido, están preparados para ir al colegio y no quieren recibir órdenes de ella, especialmente Anna, la niña mayor. Sabemos que I sabel no es su madre, que su madre se ha vuelto a casar y que Anna la odia, aunque el único pretexto es que no tiene limpia y planchada su camiseta púrpura. A los pocos minutos, aparecerá en casa Jackie, para llevar a sus hijos al colegio. Los dos la abrazan, es la madre ejemplar y tiene todo perfectamente preparado. Isabel y ella son absolutamente contrarias. Pero la película hará que tengan que entenderse a la fuerza.

- Philadelphia, en su arranque, presenta a Tom Hanks en un juicio rápido con el que será su abogado en el futuro. Parece que es un trepa sin escrúpulos que manipula la información para sacar el mayor beneficio. Es una buena metáfora porque Hanks terminará luchando contra lo que es al principio de la película.

\section{La música}

Es otra de las protagonistas del melodrama. Tiene mucha fuerza dramática ${ }^{2}$ y no se utiliza gratuitamente, sino en aquellos momentos de más tensión o dramatismo.

\footnotetext{
${ }^{2}$ El empleo de este recurso dramático se halla perfectamente definido en CALDEVILLA DOMínGUEZ, David (2000): El estilema de autor en Steven Spielberg. Tesis Doctoral. Universidad Complutense. Madrid.
} 
- En Breve Encuentro, la música remarca los silencios de la incomunicación entre Laura y su esposo. Ella ya no le quiere y a veces, no sabe que decirle. Por eso hace sonar el gramófono, que entra a formar parte de la acción pero a su vez, se convierte en banda sonora y elemento dramático.

- En la misma película, la música también toma un tinte onírico, en los sueños de Laura. En el tren, de viaje a casa, sueña que su amante, Alec, la lleva a Venecia y a París, a la ópera, a bailar... Las imágenes borrosas de esos sueños son adornadas con una música romántica.

- Sin embargo, también puede convertirse en elemento romántico, muy utilizado en Breve Encuentro. Desde el primer abrazo y el primer beso de los protagonistas, la música toma mucha fuerza, porque ellos dos están viviendo un amor secreto. La música remarca esos sentimientos contenidos que sacan al exterior y la fuerza del dolor que les supone intentar ocultarlo, hasta poder encontrarse en un lugar a solas, sin nadie que les vea.

- En películas como La buena estrella o La vida es bella, la música aparece en los momentos importantes, en las transiciones más poéticas y está muy presente en la cabeza del espectador, que las identifica y le hacen seguir con interés. La carga emocional de la música es esencial.

- En Philadelphia, Bruce Springsteen compuso la canción Streets of Philadelphia (Oscar a la Mejor Canción), que habla de la soledad y la miseria, con un tempo musical muy lento y un tono de voz marcadamente grave que denota melancolía.

\section{Conclusiones}

Todos estos elementos comunes, citados anteriormente, dan personalidad al género del melodrama (generando su corpus como 'género' de manera canónica) y demuestran su carácter e identidad propia. Sobrevive al paso de los años y evoluciona según el momento histórico. 
También está viviendo esta evolución dentro del cine. Los guionistas y directores pueden aprovechar los elementos de su fórmula (llamado 'efecto género') para seguir haciendo películas de éxito ya que su público se muestra como fiel desde los albores del cine.

El melodrama está en el imaginario del público y del espectador inteligente, que detecta esas fórmulas y quiere seguir consumiéndolas. El reconocimiento de sus características y su hueco en el imaginario del público aseguran su supervivencia por muchos más siglos.

\section{Bibliografía}

AGUILAR, Carlos (1992): Guía del vídeo-cine. Cátedra. Madrid.

CALDEVILLA DOMínGUEZ, David (2000): El estilema de autor en Steven Spielberg. Tesis doctoral. Universidad Complutense. Madrid.

\section{Vídeografía}

Películas analizadas para el estudio:

- Breve encuentro (Brief encounter, 1945, de David Lean). Datos técnicos disponibles en: www.imdb.es/title/tt0037558/ 
- Escrito sobre el viento (Written on the wind, 1956, de Douglas Sirk). Datos técnicos disponibles en: www.imdb.es/title/tt0049966/

- La buena estrella (1997, de Ricardo Franco). Datos técnicos disponibles en: www.imdb.es/title/tt0118788/

- La fuerza del cariño (Terms of Endearment, 1983, de James L. Brooks). Datos técnicos disponibles en: www.imdb.es/title/tt0086425/

- La vida es bella (La vita è bella, 1997, de Roberto Benigni). Datos técnicos disponibles en: www.imdb.es/title/tt0118799/

- Philadelphia (1993, de Jonathan Demme). Datos técnicos disponibles en: www.imdb.es/title/tt0107818/

- Quédate a mi lado (Stepmom, 1998, de Chris Columbus). Datos técnicos disponibles en: www.imdb.es/title/tt0120686/

- Todo sobre mi madre (1999, de Pedro Almodóvar). Datos técnicos disponibles en: www.imdb.es/title/tt0185125/ 